\title{
CZU:712.2:633
}

https://doi.org/10.53040/gppb7.2021.51

\section{IARBA DE FIER - SPECIE AROMATICĂ ÎN COLECTIIA IGFPP}

\author{
Chisnicean Lilia ${ }^{1}$, Gille Elvira ${ }^{2}$ \\ ${ }^{1}$ Istitutul de Geenetică Fiziologie și Protecția Plantelor, Chișinău, Republica Moldova, \\ ${ }^{2}$ Centrul de Cercetări Biologice "Stejarul”, Piatra-Neamț, România \\ e-mail:lilia.chisnicean@igfpp.md
}

\begin{abstract}
Sideritis of the Genus Sideritis - introducers of the spicy aromatic collection. Sideritis is a genus of annual and perennial plants of the family Lamiaceae. The plant has a pleasant aroma and many medicinal benefits. Foliage and inflorescences are sold as unusual tea in all Mediterranean countries. Reproduction of the plant was carried out by seedlings, which were obtained from seeds, or vegetative using cuttings from annual shoots.

As a result of introduction studies, we managed to propagate and introduce in our collection two of its subspecies - Sideritis scardica and S.taurica, as medicinal and spicy-aromatic, drought-tolerant plants.

Key words: Sideritis scardica, S. taurica, inflorescences, reproduction, plants, genus
\end{abstract}

\section{Introducere}

Printre speciile noi utilizate se numără și Iarba de fier, un gen de specii anuale și perene din familia Lamiaceae, iarba căreia actualmente este utilizată activ și comercializată ca ceai neobișnuit în toate stațiunile balneare din Turcia, Grecia, Macedonia, Bulgaria [1, 2]. În locurile de origine, această specie este cultivată, de regulă, în grădinițe pietroase și în boschete alpine ca plantă ornamentală, medicinală și aromatică [3].

Frunzele, tulpinile și florile a celor două genotipuri de Iearbă de fier studiate conțin 0,0030,006\% ulei esențial, iridoide: harpagide, 8-acetilgarpagide, flavonoide. Semințele conțin ulei gras (29$30 \%$ ) iar componenții lui sunt acizii: palmitic, stearic, oleic, linoleic, linolenic, conține vitaminele C și E, minerale [4].

Ambele tipuri de Iearbă de fier din medicina tradiţională a țărilor de origine sunt considerate un imunomodulator natural. Plantele au proprietăti hipotensive, antifebrile, diuretice, favorizează cicatrizarea rănilor, ajută la dispariția tumorilor. Prezintă activitate antibacteriană și antiprotozoică și repelentă [5]. Iearba de fier posedă și proprietăți gastroprotectoare și antiulceroase [6] .

Uleiul esențial se utilizează în industria parfumerică și cosmetologică [7]. Partea aeriană a plantei este utilizată ca condiment, frunzele și inflorescențele - ca substituitor al ceaiului cu note proaspete de citrice. Ceaiul are capacitatea de înviorare intelectuală și fizică, de tonifiere a sistemului cardiovascular și reproducător, de îmbunătățire a digestiei, de întărire a activității rinichilor și mărire a diurezei, descompunere a pietrelor uratice, mărire a longevității. Ca descoperire recentă, potrivit cercetărilor făcute în Elveția, capacitatea sa anti-oxidantă poate ajuta la prevenirea cancerului. Administrat sub formă de infuzie, decoct, mărește dispoziția și capacitatea sexuală. O mare influență asupra celor menționate o exercită componenții fitosterolici. Această acțiune este asemănătoare celei exercitate de proprii steroizi hormonali. Ceaiul poate fi utilizat și în cazul inflamației gingiilor, mucozității cavității bucale, inflamației intestinelor și căilor urinare [7].

\section{Materiale și metode}

A fost inițiat studiul cu scopul introducerii acestor valoroase specii ca Sideritis scardica și Sideritis taurica, deoarece două dintre subspeciile sale se cultivă în R.Moldova - Iarba de fir montană (Sideritis montana L.) și Iarba de fier crestată-Sideritis comosa (Rochel ex Benth). Prin analogie cu aceste subspecii, Sideritis scardica Griseb a fost introdusă și studiată ca plantă medicinală și (Sideritis taurica (Stephan) Gladkova) - Iarba de fier din Crimeea utilizată ca plantă medicinală și ornamentală.

Genul include 189 specii, dintre care în comunitatea europeană sunt mai des utilizate ca plantă pentru ceai Sideritis scardica Griseb - Iarba de fier de Pirinea și cea siriană (Sideritis syriaca ssp. taurica (Stephan) Gladkova este unul dintre tipurile Ierbii de fier, care este utilizată și ca plantă ornamentală. 


\section{Rezultate și discuții}

Ambele tipuri ale Ierbii de fier, în condițiile de sol și climatice, sunt reprezentate prin plante perene erbacee, semi-veșnic verzi. Rădăcinile sunt glandulare cu multe capete, pivotul este unul lemnos, pătrunde adânc în sol, cu un rizom puternic.

Frunzele bazale sunt mai mari și bine dezvoltate, pe când cele de pe tulpină sunt mai mici, scurt pețiolate, alungit-ovale, cu margini întregi. Florile sunt mici, de culoare galben murdar, cu bractee verde deschise foarte delicate, situate pe inflorescențe puternice în formă de somitate complexă, formate din verticile false, pe pedunculi înalți de jumătate de metru, foarte puternici, dens pubescenți, care se ramifică de la bază până la vârf. În partea de jos ale verticilelor inflorescențele sunt distanţate, iar în partea de sus sunt apropiate.

Reproducerea plantei a fost efectuată prin răsaduri, obținute din câte 100 semințe, semănate din trei locații, pe un amestec de sol, asemănător cu cel din locurile de unde este nativă specia, într-o paletă alveolară de plastic. Irigarea a fost una moderată utilizând apă stătută de temperatura camerei. Plantulele au răsărit peste 12-15 zile, cu două perechi de frunze inegale, de culoare verde suriu. Plantele tinere au fost transplantate în cupe duble - cele exterioare din plastic, iar cele interioare - din turbă. La transplantarea răsadului în câmp, pentru menținerea sistemului radicular intact, cupa de turbă a fost extrasă cu mare atenție din cea de plastic și astfel plantat răsadul într-un loc permanent.

Altă metodă de propagare a plantelor pe care s-a folosit a fost cea vegetativă, folosind câte 100 butași din lăstari anuali. Cele mai bune rezultate la înrădăcinarea butaşilor au fost observată la materialul pentru butășire recoltat primăvară devreme.

Tabelul 1

Metodele de multiplicare la două specii din genul Sideritis

\begin{tabular}{|c|c|c|c|c|c|c|c|c|c|c|}
\hline Metoda & \multicolumn{6}{|c|}{ Sideritis scardica } & \multicolumn{5}{c|}{ Sideritis taurica } \\
\hline Prin semințe & 2019 & 2020 & 2021 & $\mathrm{X}$ & $\mathrm{Sx}$ & 2019 & 2020 & 2021 & $\mathrm{X}$ & $\mathrm{Sx}$ \\
\cline { 2 - 13 } & 89 & 91 & 92 & 90,6 & 0.79 & 86 & 94 & 90 & 90.0 & 3,26 \\
\hline Prin butași & 88 & 89 & 90 & 89,0 & 0.60 & 89 & 90 & 92 & 90,3 & 1.25 \\
\hline
\end{tabular}

Lăstari semilignificați anuali, de 5-7 cm lungime, au fost tăiați și plantați în sere într-un amestec de sol, humus și nisip (1: 1: 1), deasupra au fost acoperiți cu un strat de nisip amestecat cu turbă 1,5 $-2 \mathrm{~cm}$ cu o suprafață de nutriție de $4 \times 5 \mathrm{~cm}$ la o adâncime de 4-6 cm și irigată abundent. Până la plantare butașii au fost tratați (înmuiați) în stimulator de înrădăcinare industrial - kornevin.

În termen de 35-40 de zile, au apărut rădăcinile și plantele au început să crească fiind plantate într-un loc permanent, pe sol ușor, pregătit, dar hrănitor.

Ambele tipuri ale Ierbei de fier, Sideritis scardica cât și S. taurica, procentul de înrădăcinare, constituind cca $87-90 \%$, formând o rădăcină puternică, sănătoasă.

Plantele speciilor Sideritis scardica și S. taurica preferă pantele însorite și luminoase de sud. Ele sunt rezistente la îngheț, nu se tem de curenți reci, dar este mai bine să evităm pantele nordice, cu vânt permanent. Solul pentru creșterea plantelor este potrivit (selectat), fiind unul nisipos și stâncos, cu un conținut redus de substanțe nutritive și o reacție alcalină sau ușor alcalină, bine drenat.

Îngrijirea plantelor speciei Sideritis scardica și S. taurica este simplă și constă în irigare și fertilizare cu îngrășăminte organice de tipul vermicompost - în special la plantele tinere. A fost de asemenea făcute irigări în apa cărora au fost dizolvate mase aluviale, pentru sporirea creșterii.

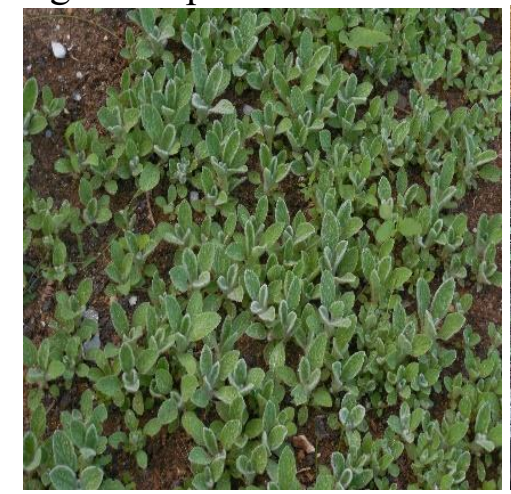

Plantule rezultate din semințe Plante obținute prin butășire

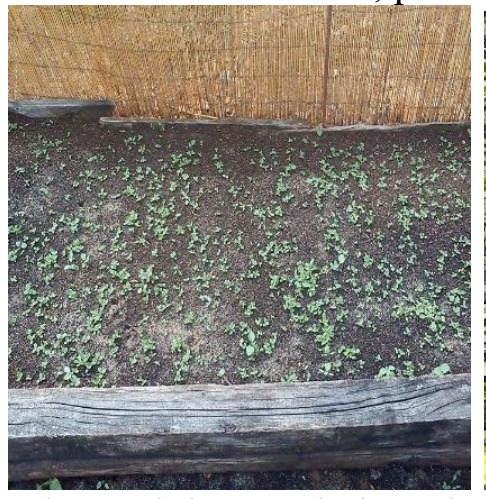

195

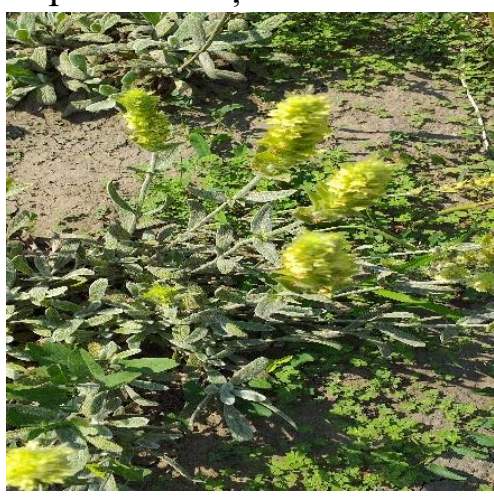

Planta matură la înflorire 
Lucrările ulterioare au constat în afânarea solului în timpul compactării sale pentru o mai bună aerare a rădăcinilor și distrugerea buruienilor. Au fost făcute curățiri de sanare a tufelor de inflorescențele de anul trecut și recoltarea frunzelor uscate la plantele de Sideritis scardica și S. taurica la începutul primăverii, înainte de desfacerea mugurilor.

În primul an după plantare (2019), speciile au avut o creștere și dezvoltare mai lentă, cu toate că au format toate elementele habitusului. Plantele n-au atins talia cuvenită. Numărul de frunze a fost redus, ele fiind de dimensiuni medii. Verticilele florale au fost de asemenea reduse și nu au format semințe.

Anul 2020 a fost unul cu deficiență de umiditate și cu toate că speciile date nu sunt capricioase, cantitatea de producție de frunze și flori a fost mică. Plantele n-au reuşit să înflorească deplin, iar unele verticile s-au uscat, neajungând la faza de înflorire.

A fost deosebit după majoritatea parametrilor anul 2021 - cu precipitații abundente și necesarul de temperaturi pozitive. Talia plantelor a avut valori maxime de $52.7 \mathrm{~cm}$ și $50.6 \mathrm{~cm}$ la ambele specii.

Tabeluul 2.Indicii morfologici medii al plantelor speciilor Sideritis scardica și S. taurica, 2019-2021

\begin{tabular}{|c|c|c|c|c|c|c|c|c|c|c|}
\hline Indicii & \multicolumn{5}{|c|}{ Sideritis scardica } & \multicolumn{5}{c|}{ Sideritis taurica } \\
\hline & 2019 & 2020 & 2021 & $\mathrm{X}$ & $\mathrm{Sx}$ & 2019 & 2020 & 2021 & $\mathrm{X}$ & $\mathrm{Sx}$ \\
\hline Talia plantelor, cm & 47.3 & 52.4 & 62.6 & 54,7 & 1,02 & 45.0 & 52.2 & 53.2 & 50.06 & 1,1 \\
\hline Lungimea frunzei, cm & 12,2 & 10,6 & 14,1 & 12,3 & 0.8 & 12.0 & 9,8 & 12.4 & 11.4 & 1.0 \\
\hline Lățimea frunzei, cm & 5.4 & 4.2 & 6.2 & 5.3 & 0.6 & 5.2 & 4.6 & 6.3 & 5.4 & 0.7 \\
\hline Masa frunzelor, g & 64.4 & 55.4 & 68.8 & 62.8 & 2.2 & 62.4 & 50.8 & 63.6 & 61.6 & 1.9 \\
\hline Cota frunzelor în masa totală, \% & 53 & 45 & 58 & 52.0 & 4,3 & 48.2 & 44.4 & 55.6 & 49.4 & 3.7 \\
\hline $\begin{array}{c}\text { Numărul total de } \\
\text { inflorescențe, unități: }\end{array}$ & 17 & 40 & 53 & 36,3 & 1.7 & 20 & 34 & 54 & 36.0 & 1.2 \\
\hline Lungimea inflorescenței, cm & 14 & 10 & 17 & 13.7 & 0.9 & 13 & 12 & 15 & 13.3 & 1.0 \\
\hline Masa inflorescențelor, g & 35 & 20 & 53 & 35.3 & 4.2 & 33 & 18 & 52 & 34.3 & 3.3 \\
\hline $\begin{array}{c}\text { Cota inflorescențelor în masa } \\
\text { totală, \% }\end{array}$ & 42 & 37 & 52 & 43.6 & 3.1 & 40 & 38 & 49 & 42,3 & 4.0 \\
\hline
\end{tabular}

Atât lungimea și lățimea frunzelor a variat în valorile au fost mai mari decât în anii precedenți. Cota frunzelor a atins valori maxime de 52.0- 49.4\%, cota inflorescențelor a constituit 43.6- 42.3\% materia primă.

Calitatea materiei prime a fost excelentă, cu aromă și gust specific. Plantele au format multe semințe, care după aprecierea controlului de laborator vor fi utilizate pentru a obține plante direct în teren deschis. Speciile date sunt de perspectivă, predestinate în calitate de materie primă, la prepararea ceaiurilor medicinale, pentru obținerea extractelor și în calitate de condiment alimentar.

Nu s-au observat dăunători și boli la plante studiate. Plantele speciilor testate sunt tolerante la înghețurile de iarnă, dar este mai bine să mulcim solul din jurul plantei pentru a reduce riscul de schimbări bruște de temperatură în perioada rece.

\section{Concluzii}

- Ambele metode de multiplicare sunt eficiente, doar că semințele sunt mai lesne de păstrat, fără riscuri de îngheț sau uscare la care sunt supuse plantele în teren deschis.

- Iarba de fier posedă o aromă plăcută și beneficii medicinale, colectarea frunzelor și inflorescențelor pentru ceai se efectuează în parcursul verii, încercând să se taie nu mai mult de o treime din masa vegetativă a plantei, de la răsărire și până la înflorirea în masă.

- La multiplicarea prin diferite metode a speciilor Sideritis scardica și S. taurica s-au obținut rezultate valoroase, speciile fiind recomandate în calitate de plante condimentate, aromatice și medicinale.

- Material, pentru multiplicarea vegetativă, cat și prin semințe sunt în cantități suficiente pentru a fonda plantații mici sau a le utiliza în alte scopuri.

- Speciile pot fi recomandate firmelor farmaceutice și producătorilor autohtoni de ceaiuri medicinale pentru studiu și utilizare în calitate de materie primă.

- Pe lângă faptul că speciile posedă calităţi curative și gustative deosebite, ele pot fi utilizate cu succes pentru decorarea boscetelor, rocariilor în calitate de plantă decorativă.

- $\quad$ Plantele ambelor specii nu-si pierd aspectul nici în timpul iernii, fiind prețuite pentru această calitate. 
Cercetările au fost realizate în cadrul proiectului Programului de Stat 20.80009.5107.07 "Diminuarea consecinţelor schimbărilor climatice prin crearea, implementarea soiurilor de plante medicinale şi aromatice cu productivitate înaltă, rezistente la secetă, iernare, boli, ce asigură dezvoltare sustenabilă a agriculturii, garantează produse de calitate superioară, predestinate industriei de parfumerie, cosmetică, farmaceutică, alimentară”, finanţat de Agenţia Naţională pentru Cercetare şi Dezvoltare.

\section{Bibliografie}

1. CHARLOTTE LINDQVIST, VICTOR A. ALBERT. 2002. Origin of the Hawaiian endemic mints within North American Stachys (Lamiaceae). _-American Journal of Botany 89(10):17091724. Sideritis (англ.). The Plant List. Version 1.1. 2013).

2. GONZÁLEZ-BURGOS, E., CARRETERO, M.E., GÓMEZ-SERRANILLOS, M.P.. Sideritis spp.: Uses, chemical composition and pharmacological activities-A review. Review Article Journal of Ethnopharmacology. Vol. 135, Issue 2, 17 May 2011, P. 209-225

3. ЮЗЕПЧУК, C. В. Род 1250. Железница - Sideritis L. // Флора CCCP : в 30 т. / начато при рук. и под гл. ред. В. Л. Комарова. - М. ; Л. : Изд-во АН СССР, 1954. - Т. 20 с. 253-273. -с.

4. YANEVA, IL., BALABANSKI, V. History of The Uses of Pirin Mountain Tea (Sideritis Scardica Griseb) In Bulgaria. 2013. Bulgarian Journal of Public Heal 56 Th Vol.5 № 1

5. TODOROVA, M., TRENDAFILOVA, A. Sideritis scardica Griseb., anendemic species of Balkan peninsula: Traditional uses, cultivation, chemical composition, biological activity. Journal of Ethnopharmacology 152, 2014, 256-265.

6. TADIĆ, V.M, JEREMIC, I., DOBRIC, S., ISAKOVIC, AL., MARKOVIC, I., TRAJKOVIC, V, BOJOVIC, D., ARSIC, I. Anti-inflammatory, gastroprotective, and cytotoxic effects of Sideritis scardica extracts. Planta Med. 2012 Mar;78(5):415-27. doi: 10.1055/s-0031-1298172. Epub 2012 Jan 24.

7. KOEDAM, A. (1986). Volatile oil composition of greek mountain tea (Sideritis spp.). J. SCI. FOOD AGRIC., 36, 681-684.

8. http://www.hypericum-plant.ro/cea.../ceai-iarba-de-fier.html 